\title{
A teologia da vida em
}

Luiz Gonzaga

The Theology of life in Luiz Gonzaga

\section{Elias Wolff*}

\section{Luiz Tarquinio Pontes Neto*}

Texto enviado em

12.04.2019

aprovado em

04.06.2019

V. 10 - N. $22-2020$

*Doutor em Teologia (Pontifícia Universidade

Gregoriana). Mestre em Filosofia (Pontifícia Universidade Santa Croce). Membro do Programa de Pós-Graduação em Teologia da PUCPR. Contato: elias. wolff@pucpr.br

**Pós-doutorando em teologia - PUCPR. Contato: prluiztarquinio@gmail.com

\section{Resumo}

Luiz Gonzaga foi um dos nomes mais conhecidos e divulgados da música popular brasileira. Seu cancioneiro é pródigo em alusões ecológicas. Sua grande afeição à criação divina chama à atenção dos ouvintes. Gonzaga, no entanto, não somente estimava a natureza, mas pregava, já nos seus dias, a responsabilidade ecológica. Como uma espécie de São Francisco do sertão, conversou também com plantas e animais, chamando-os de irmão, pois possuía a clareza de que provinham da mesma matriz. Ao se referir ao juazeiro, chamava-o de "Meu velho amigo" e requeria dele respostas claras para seus questionamentos, assim como Francisco de Assis, padroeiro da ecologia e protetor dos animais, que soube enxergar a face de Deus por meio do mundo criado. Em Gonzaga, vê-se presente os fundamentos do homo viridi, do homem ecológico e verdejante, que prefere caminhar ao lado da natureza e não sobre ela, elegendo a parceria em lugar do grilhão e do chicote, sujeito que se faz mordomo ecológico a cuidar do que não lhe pertence, aquele que entende o real sentido contido em Gênesis do dever humano em relação à terra e aos seres criados.

Palavras-chave: Luiz Gonzaga. Sertão.

Canções ecológicas. Homo viridi. 


\section{Abstract}

Luiz Gonzaga was one of the best known and most popular names in Brazilian popular music. His songbook is prodigal in ecological allusions. His great affection for divine creation draws the attention of the hearers. Gonzaga, however, not only valued nature, but preached ecological responsibility even in his day. Like a species of San Francisco from the deserts, he also talked to plants and animals, calling them brother, because he had the clarity that they came from the same source. When he referred to the plant, he called him "My old friend" and demanded of it clear answers to his questions, just as Francis of Assis, patron of ecology and protector of animals, knew how to see the face of God through the created world. In Gonzaga, we see the foundations of homo viridi, who prefers to walk alongside nature and not on it, choosing the partnership instead of the shackle and the whip.

Key words: Luiz Gonzaga. Deserts. Ecological songs. Homo viridi.

\section{Introdução}

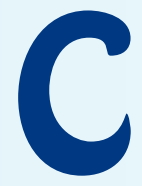

onta-se uma interessante história acerca do primeiro filósofo, Tales de Mileto, que era conhecido por gastar horas olhando para o céu, tentando desvendar os mistérios dos astros, tendo sido o primeiro homem a prever um eclipse. Entretanto, numa de suas andanças, Tales tropeçou e caiu em um grande buraco. A pessoa que o socorreu, resgatou o filósofo sob o ritmo de algumas risadas, dizendo-Ihe: "Ei, Tales, como você há de saber o que se passa no céu se não consegue ver o que se passa na terra" (CHAUÍ, 2012, p. 10).

Não raras vezes, a grande atenção dispensada aos céus, subtrai as retinas da grandiosidade simples do cotidiano, das coisas comuns, daquelas que passam desapercebidas, dos pedaços pequenos de vida vistas em toda parte, mudas em suas inerências, como um punhado de terra, algumas plantas e animais, hipossuficientes perseguidos à revelia, sem proteção, em cujos libelos de defesa encontram-se laudas vazias, a exceção de pouquíssimos representantes que saíram em sua proteção, advogando o valor do que se inverte ao grande, vendo beleza e assumindo responsabilidade pelos variados anões da terra, embasbacando- 
-se não somente com as grandes cataratas, os imensos mares e as exaltadas montanhas e florestas, mas percebendo na mudez das pequenas mudas de todo verde o canto divino, e, no hálito de cada vivente, o sopro do Criador, que viram riqueza na simplicidade e importância naquilo que aos homens cega, que mudaram os olhos androcêntricos para enxergar a humanidade como parte da natureza, não para rebaixá-la, mas responsabilizá-la, passando a visualizar como irmão o todo-criado, nos animais, parte de sua família, pois derivado da mesma matriz.

Um desses homens, que viu tais invisibilidades, foi Luiz Gonzaga. Seu cancioneiro está recheado de passagens que dignificam a terra, os animais e os homens, todos criados por Deus. O "Rei do Baião" (LACERDA, 1999, p. 49), como era carinhosamente chamado por seus admiradores, em sua obra, exaltou a criação, observando embasbacado a beleza do comum da vida. Cantou a natureza e sua deslumbrante beleza, mesmo quando esta não lhe concedia os frutos esperados.

Não enxergou a terra como linha de montagem, onde peças e mercadorias seriam produzidas, mas dotada de valor em si, não como instrumento, mas como fim nela mesma, dando-lhe a dignidade desejada por Deus, ensinando aos homens o dever de cuidado e proteção. Celebrou, em seus versos, do jumento aos pássaros de asas brancas, com rimas simples, afastadas dos caprichos exagerados, em versos desenhados a partir de um português distante da pureza lusitana.

Seus poemas têm cheiro de terra batida, suas músicas possuem partituras de topografia como dos enormes campos em que viveu, sua voz ecoa a grita dos famintos e alvejados, dos que ficaram com a parcela mais magra do solo, mas que, ainda assim, amavam sua terra, pois nela se viam, compreendendo-se como parte, porções, punhados dela. "Luiz Gonzaga tem sido objeto de estudo nas áreas de jornalismo, Ciências Sociais e literatura, Comunicações, Música, entre outras. Foi estudado por diversos profissionais: professores, musicólogos, estudantes de filosofia..." (NASCIMENTO, 2018, p. 17) Contudo, sua vida não tem sido, 
na mesma dimensão, explorada na teologia. Esse artigo, portanto, visa a identificar e analisar o trabalho Luiz Gonzaga à luz da ecoteologia.

\section{Luiz Gonzaga: o homem, sua terra e seu tempo}

Luiz Gonzaga - nome dado por ter nascido no dia de Santa Luzia e por ser complemento do nome de São Luiz (HOUAISS, 2006, p. 327) - , nasceu na cidade de Exu, no interior de Pernambuco, na base da serra do Araripe, numa casa de reboco, construída a partir de barro batido encaixado por entre vigas de madeira (NASCIMENTO, 2018, p. 31). Recolhia-se no interior do seu oikos particular como abraçado por pedaços rústicos de árvores preenchidos por punhados de terra amaçada. Essa foi sua morada no interior de Pernambuco desde o seu natal. Sua casa de terra a ele, de pó, se misturava, preconizando futuro vaticínio de uma vida amalgamada à matéria prima mais rústica da natureza. Do abraço recebido da casa simples, retribuiu em mil, por meio de versos produzidos em louvor à criação. Uma de suas irmãs, Socorro Januário, afirmara ter escutado sua mãe dizer que Luiz Gonzaga veio ao mundo para ser do povo até a morte (HOUAISS, 2012, p. 327). Certamente, foi do povo e para ele, entregando-se num alegre festival em favor da vida.

Nasceu abaixo dos poderosos raios solares de uma das porções mais áridas do solo pernambucano, em 13 de dezembro de 1912. Segundo Ângelo:

Da mãe, Gonzaga herdou o coração; e do pai o talento, não cansava de dizer. Juntos, amor de mãe e talento de pai, num homem como ele, nascido sob o sol escaldante e brabo das terras nordestinas e criado no oco do muno, só poderiam resultar em força de vontade e muita coragem de viver. Com o coração de mãe e talento de pai, não há quem se perca na vida (Apud, LACERDA, 1999, p. 49)

Foi criado distante dos centros urbanos e do recheio do concreto. Nas vias de sua vida avistava-se muito mais as árias dos passaredos do 
que as passagens barulhentas dos carros e suas buzinas. Andava a pé, e quando podia, pelos pés dos animais de montaria, com os quais era íntimo. Das plantas do sertão, conhecia o nome e as respectivas floradas. Sabia o tempo das chuvas e das longevas estações de seca, que a tudo empalhava e deixava sem vida, e que, não raras vezes, reiterava o adiamento das conhecidas trovoadas, adiando, assim, o verdejar das campinas e o sustento dos sertanejos. Acerca da aridez daquelas cercanias, escreveu Euclides da Cunha:

Fere-a o sol e ela absorve-lhe os raios, e multiplica-os e reflete-os, e refrata-os, num reverberar ofuscante: pelo topo dos cerros, pelo esbarrancado das encostas, incendeiam-se as acendalhas da sílica fraturada, rebriIhantes, numa trama vibrátil de centelhas; a atmosfera junto ao chão vibra num ondular vivíssimo de bocas de fornalha em que se pressente visível, no expandir das colunas aquecidas, a efervescência dos ares; e o dia, incomparável no fulgor, fulmina a natureza silenciosa, em cujo seio se abate, imóvel, na quietude de um longo espasmo, a galhada sem folhas da flora sucumbida. (1984, p. 14)

Foi neste ambiente inóspito que Gonzaga cresceu e fora forjado para um futuro florescente. Inobstante o despontar de suas cores e flores, jamais se esqueceu ou negou suas origens. A prosperidade artística não Ihe apagou da pele os calos juvenis, nem desvencilhou de continuar sentindo, nos climas suavizados do Sul, o vento quente e seco de Exu. O barulho dos trens e fábricas não calou de si a paradoxal dor e delícia do sertão da lua e da seca.

Ao tempo de sua infância, em Exu, distante das grandes cidades industrializadas e modernas, a vida girava em torno dos trabalhos na lavoura, as celebrações, ritos católicos e os folguedos. Entre estes, o principal eram as festas juninas: São João e São Pedro, que se confundiam exatamente com o tempo da colheita do amendoim, da mandioca, milho e feijão. Desde pequeno, Luiz Gonzaga conviveu com a música e com a sanfona. Seu pai, o sanfoneiro Januário, além de tocador, conser- 
tava e afinava sanfonas, o que lhe proporcionou grande intimidade com o instrumento. Era comum a passagem constante de violinistas e sanfoneiros nas ruas da cidade. Assim, Luiz Gonzaga começou a ter contato com a música, incentivado por seu pai. Andando e correndo pelas ruas, o menino Gonzaga, sem perceber, ia sofrendo influências musicais, ouvindo os cantadores e as novenas proferidas por sua mãe, Santana. As marcas musicais do Araripe estão por toda a obra de Luiz Gonzaga. (NASCIMENTO, 2018, p. 30).

Ainda em Exu, já era reconhecido por seu potencial artístico. Em 1930, incorporou-se às forças armadas em Fortaleza, fugindo de uma disputa com o pai de uma namorada. Três anos depois, recebeu do exército o título de tambor-corneteiro, tendo dado baixa em 1939, quando se aventurou no Rio de Janeiro. Na zona do mangue carioca, ao se apresentar num dos bares da região, um grupo de estudantes cearenses, pediu-lhe que tocasse uma levada nordestina, o que fez de imediato, sendo em grandemente ovacionado. Conforme Nascimento (2018, p. 33) depois daquela experiência, Luiz Gonzaga modificou seu repertorio musical, deixando os ritmos estrangeiros, como tangos, fados e valsas para encarar movimentos de raiz, como o xote, o baião, o forró, o coco, o xaxado e o frevo. A partir desta mudança, Luiz Gonzaga começou a fazer sucesso, recebendo, inclusive, nota máxima no conhecido programa da rádio Tupi, "Calouros em Desfile", apresentado por Ari Barroso. A partir daí, a carreira de Luiz Gonzaga ganhou significativa ascendência. Certo dia, ao ver o cantor catarinense, Pedro Raimundo, com vestimentas típicas do gaúcho, tomou coragem e passou a calçar a indumentária do vaqueiro do sertão, e, juntamente, com seus parceiros Humberto Teixeira e Zé Dantas, produziram canções que marcaram uma época. (NASCIMENTO, 2018, p. 33).

Do sertão, Gonzaga trouxe o chão. Mesmo empoeirada e estéril, era de sua terra enamorado. Recanto de parcas colheitas, mas de grandes horizontes e céus marinhos imensos. Das minguadas segas, Gonzaga colheu uma vida abundante e vocação poética, que coseu a ritmos apren- 
didos dos variados gritos de sofrimento diuturnamente escutados. Da barbaridade, derivou, como em milagre, uma singeleza musical desconhecida e bela, como a flor branca que brota no escanteio do mandacaru.

A tristeza, a luta e a dor, foram as inspirações de Gonzaga para produção de um cancioneiro singelo e profundo, que venerava o povo simples e a natureza. O mal para ele teve força contrária, ensejou-Ihe um coração compassivo, aberto não somente para reverberar os clamores dos pobres, mas também para enxergar a beleza existente em toda parte da vida. Continuou sendo um homem ecológico, que cantava uma música verde, em acordes de aves, ansioso por hipnotizar o sol fazendo-o dormir por trás de nuvens, de cujo ardil a natureza recalcitrava se desvencilhar, permanecendo marrom. Mesmo assim, declamava-Ihe odes em lirismos sertanejos e quentes. A carestia lhe engendrou raízes densas e profundas, por meio da qual sugou, do fundo, água para regar suas inspirações a fim de dessedentar a alma dos nordestinos. Ecoando o Conselheiro, repetia que o sertão um dia viraria mar, vendo um futuro de brilhante fartura para a escassez do presente.

Mas o sucesso de Luiz Gonzaga foi acelerado pelo "espirito do tempo". À época, buscava-se encontrar o brasileiro-raiz. Fervilhava entre os intelectuais o anseio em descortinar o brasileiro que jazia por trás do sujeito colonizado daqueles dias, a refletir padrões e costumes ádvenas. Desejava-se cavar mais fundo a alma do brasileiro para retirar as indumentárias continentais e encontrar o homem das Pindoramas. Tal era o anseio dos modernistas, que buscavam maior independência em relação à interferência estrangeira no país. Luiz Gonzaga desenhava o estereótipo de liberdade pugnado. Agregado a isso, o caldeamento racial encontrado nas etnias do nordeste, síntese das variadas raças, europeus, negros e indígenas, incentivou a noção de uma maior brasilidade do nordestino. Gonzaga, portanto, refletia a persona brasilis imaginada pelos modernistas. Quiçá, sem dar-se conta, tenha simbolizado o extrato de uma poesia pau-brasil, tonificada por odes e rimas populares da caatinga, região, até então, pouco conhecida dos sulistas. Destarte, o 
sertanejo ganhou a pecha de brasileiro original, devido ao resguardo das influências cosmopolitas. (NASCIMENTO, 2018, p. 39), que vivia numa terra distante, região ignota, como disse Euclides da Cunha (1984, p. 7) ao abordar a geografia do sertão:

Abordando-o, compreende-se que até hoje escasseiem sobre tão grande trato de território, que quase abarcaria a Holanda $\left(9^{\circ} 11^{\prime}-10^{\circ} 20^{\prime}\right.$ de lat. e $4^{\circ}-3^{\circ}$ de long. O.R.J. ), notícias exatas ou pormenorizadas. As nossas melhores cartas, enfeixando informes escassos, lá têm um claro expressivo, um hiato, Terra ignota, em que se aventura o rabisco de um rio problemático ou idealização de uma corda de serras.

As terras do semiárido eram muitas vezes inacessíveis e desconhecidas, completamente apartadas do Brasil desenvolvido. Isso é relatado na canção "Estrada de Canindé": "Ai, ai, que bom, que bom, que bom que é, uma estrada e a lua branca, no sertão de Canindé. Automóvel lá nem se sabe se é "home" ou se é "muié", quem é rico anda em burrico, quem é pobre a pé". (GONZAGA; TEIXEIRA, 1951). Os governos haviam decidido mante o sertão ligado ao Brasil central e desenvolvido por meio dos conhecidos Coronéis, que, empregando meios legais ou não, mantinham um quinhão mínimo de ordem na região (Goís, 2013, p. 34). Adicionado a isso, afirma Nascimento (2018, p. 21):

O discurso modernizador do governo de Getúlio Vargas, direcionado para a busca de uma identidade brasileira, compreendida, na época, não em termos de uma diversidade cultural, mas em termos de autenticidade, visava ao processo de emergência da indústria cultural no Brasil. Fazia-se necessário encontrar o elemento representativo da nacionalidade, o que motivou o interesse pela cultua popular. Foi nesse cenário que Luiz Gonzaga começou a fazer sucesso.

\section{Análise do Cancioneiro de um homem da terra}

Antes de mais nada, Luiz Gonzaga era um homem da terra. Em sua música "Boiadeiro" (GONZAGA, 1981) declara: "eu sou mesmo um ho- 
mem da terra". Será que compreendia exatamente que estava afirmando o primado teológico da tradição judaico-cristã referente à criação do homem? Talvez. O fato é que não somente ele, mas todos os homens são feitos do pó da terra, do barro amassado por Deus. Ao construir o homem, a matéria prima utilizada foi 'adamah, terra, donde surgiu o nome do próprio Adão, cuja essência é terra misturada com Deus. A humanidade é o conjunto de homens da terra, feitos a partir dela, a fim de cuidá-la, cultivá-la e guardá-la.

Daí o fato de, simbolicamente, poder se considerar a terra como a "Grande mãe", tal como se assume hoje a consciência do ser humano em relação à criação como um todo, como berço de vida o Criador trabaIha para modular o ser humano e as demais criaturas. Paradoxalmente, esta mãe é também filha, pois se cuida, também deve ser cuidada, se protege, deve também receber proteção; se dá vida, também a recebe das mãos humanas. Ao se voltar contra a terra e maltratá-la, o homem demonstra ingratidão, falta de reverência com a matéria prima utilizada para forjá-lo. Um dos dez mandamentos contidos na Lei Mosaica é honrar pai e mãe. Isso se deve ao fato não somente do devido respeito àqueles que se empenharam e trabalharam em favor dos seus filhos, mas também porque os filhos são frutos dos pais. O fundamento é marcar as regras do ideário da gratidão. Com as reservas devidas, há semeIhante paralelo em relação à necessidade de se honrar a terra por ela ser o fundamento mediato da constituição humana.

Na canção, "Juazeiro”, ao modo de São Francisco, Gonzaga pleiteava uma conversa com este conhecido arbusto do sertão, perguntando onde estava, por onde andava aquela a quem amava, como segue:

Juazeiro, Juazeiro,

Me arresponda, por favor,

Juazeiro, velho amigo,

Onde anda, o meu amor.

Ai juazeiro, ela nunca mais voltou,

Diz, Juazeiro, onde anda, meu amor

Ai Juazeiro...(GONZAGA; TEXEIRA, 1949) 
Ao se referir ao juazeiro, chamava-o de "Meu velho amigo" e requeria dele respostas claras para seus questionamentos, assim como Francisco de Assis, padroeiro da ecologia e protetor dos animais, que soube enxergar a face de Deus por meio do mundo criado. Francisco viveu contemplando a majestosa obra da criação. Das formigas ao astro rei, em tudo via fagulhas divinas. No seu belo louvor ao sol, ele o chama irmão, filho do mesmo Pai, e à água de irmã que refrigera e revigora, saindo do chão em odes de aleluia! (AQUINO, 2010, p. 02). Ex positis, percebe-se, assim, a intensa relação de Gonzaga com o magistério franciscano pautado na ecologia. Sua relação com a natureza em muito se assemelha ao daquele que foi considerado o ecólogo por excelência. Gonzaga se embasbacava diante do criado, e oferecia venerável respeito ao produto das mãos divinas.

Por ter crescido num ambiente rural, Gonzaga conhecia profundamente os animais e os ovacionava em suas canções. Compadecia-se, por exemplo, da dor do Assum Preto - pássaro mais conhecido como graúna, cujo belo canto é admirado em diversas regiões - por ter tido seus olhos vazados pelo dono para poder cantar melhor. Identificava seu coração ao do pássaro, esmigalhado por um amor, que também tinha tirado toda luz dos seus olhos:

Tudo em vorta é só beleza,

Sol de Abril e a mata em frô, Mas Assum Preto, cego dos óio Num vendo a luz, ai, canta de dor

Mas Assum Preto, cego dos óio

Num vendo a luz, ai, canta de dor

Tarvez por ignorança

Ou mardade das pió

Furaro os óio do Assum Preto

Pra ele assim, ai, cantá mió

Furaro os óio do Assum Preto

Pra ele assim, ai, cantá mió

Assum Preto veve sorto

Mas num pode avuá

Mil vez a sina de uma gaiola

Desde que o céu, ai, pudesse oiá 
Mil vez a sina de uma gaiola

Desde que o céu, ai, pudesse oiá

Assum Preto, o meu cantar

É tão triste como o teu

Também roubaro o meu amor

Que era a luz, ai, dos óios meus

Também roubaro o meu amor

Que era a luz, ai, dos óios meus (GONZAGA; TEXEIRA, 1950);

Interessante notar, nestes versos, inicialmente, a admiração de Gonzaga com o mundo ao redor. "Tudo em volta é só beleza", "e a mata em frô". A criação de Deus é vista com fascinação, o que reporta ao mesmo deslumbramento de Deus ao terminar seus atos criativos. A obra criada satisfez a vontade de Deus, estava adequada ao seu propósito, e, além disso, se fazia esteticamente majestosa. Nada poderia sair das mãos do Criador que não fosse perfeito nos mais variados sentidos. Embora a Queda tenha afetado a perfeição do mundo criado, não o corrompeu por completo, tanto que se pode ainda constatar o resplendor estético na natureza. Certamente não como outrora, mas em resíduos consistentes e cativos, que desembocarão para a perfeição no porvir. Gonzaga tinha olhos para perceber a tonificação positiva da vida, muito mais do que enxergar tão somente as regiões em mazelas. Seus olhos tinham focos apropriadamente otimistas. Por outro lado, o poeta queixa-se devido ao fato de um pássaro não dividir com ele o gosto desta beleza, porque estava cego. Suas vistas foram feridas para satisfazer os ouvidos egoístas do seu dono. Em troca do gozo momentâneo, vistas escureceram, o que, para Gonzaga, era uma injustiça. Não importava que fosse um simples animal que se vestisse de penas, era um ser criado com olhos por Deus, e que não competia ao homem proferir tal violência a fim de patrocinar um deleite espúrio. Percebe-se, entretanto, ainda aqui, que a visão de Gonzaga era positiva, preferindo encontrar em vez da maldade humana, no caso notória, a ignorância. "Tarvez por ignorança" é que tenha o humano patrocinado o espetáculo macabro, cegando os olhos do assum. Claramente, Gonzaga percebia a acinte praticada, mas escolheu dissolvê-la por meio, quiçá, de um autoengano, 
adicionando acento à sua constante preferência de absolvição, nalguns casos exagerada.

No inusitado clássico, "Apologia ao Jumento", o poeta de Exu, assevera que:

o jumento é nosso irmão, sim, o jumento é nosso irmão, quer queiram quer não. $O$ jumento sempre foi o maior desenvolvimentista do sertão, ajudou o homem na luta diária, ajudou meu sertão a se desenvolver, arrastou água para casa do homem, arrastou madeira, lenha, tijolo, cal, telha, fez açude, estrada de rodagem, fez a feira e serviu de montaria. E o homem o que é que lhe dá? Castigo, pau nas pernas, nos lombos, no pescoço, nas orelhas, e quando o bichinho não aguenta mais o peso de uma carga e se deita no chão, o homem faz é um foguinho debaixo do rabo dele. O jumento é bom, o homem é mal. (GONZAGA; CLEMENTINO, 1967)

Tomando por empréstimo as palavras do Padre Vieira, Gonzaga defende o jumento, alegando que, além de ser um irmão, foi um dos maiores responsáveis pelo desenvolvimento do sertão, ao auxiliar o homem nas mais variadas tarefas, puxando lenha, carregando água, fazendo açudes, mas este em vez de reconhecer seu valor, maltrata-o com severos castigos. Arrematando: "Mas eu gosto dele, porque ele é servidor que é danado! Animal sagrado! Jumento, meu irmão, eu reconheço teu valor! Tu és um patriota! Tu és um grande brasileiro!" (GONZAGA; CLEMENTINO, 1967). Gonzaga reflete ter a compreensão da sacralidade do animal, estendendo, em conclusão, a deferência para o todo criado por Deus.

Gonzaga transcende sua humanidade, misturando sua alma a dos animais, em respeito àquilo que Deus criara. Ele sabia que o homem não pode ser considerado déspota da criação, mas mordomo, aquele que administra e cuida do que não lhe pertence. Gonzaga parecia perceber que o homo sapiens deve ser também homo viridi, aquele que se reconhece desabsolutizado, parte da natureza, membro de uma comunidade intercambiante de seres que se oferecem e requisitam, que se 
doam, mas também requerem, numa simbiose entre a carne e o verde. Ao fotossintetizar-se, o homo viridi deixa a potesta despótica, tornando-se parte integrante, gestor responsável que regressa à vocação primeira de guardar o jardim, deixando a ilusão das alturas gnosiológicas e dominadoras proposta pela Serpente para encontrar-se com a vocação da primeira simplicidade, quando estava nu e não sentia vergonha. $A$ virada antropocêntrica enganou o homem ao pretender um pensamento idólatra acerca de si mesmo, como se a criação fosse manipulável ao seu talante, a ponto de poder cegar um animal para que ele pudesse cantar afinado, preferindo a fugacidade do som efêmero aos olhos de um animal.

Mas a atenção de Gonzaga, não deixava o homem, coroa da criação, à revelia dos seus libelos e conceitos. Muito se compadecia com o sofrimento do povo do semiárido brasileiro, onde a escassa chuva machuca os habitantes de uma terra abrasada. Devido aos intensos períodos de sol escaldante que empalha o verde, os homens se transformam em retirantes, em constante diáspora para os grandes centros urbanos.

Ansioso por uma melhor distribuição de renda e justiça, o "Rei do Baião" não se calava diante da violência praticada contra os mais humildes. No poema historiado, "Morte do Vaqueiro" (GONZAGA; BARBALHO, 1963), Gonzaga pede justiça para seu primo, Raimundo Jacó, um conhecido vaqueiro de Exu, morto por interesses políticos, sem qualquer ação formal do Estado para encontrar os partícipes envolvidos no homicídio de um pobre que lutava por seus direitos:

\footnotetext{
Numa tarde bem tristonha

Gado muge sem parar

Lamentando seu vaqueiro

Que não vem mais aboiar

Não vem mais aboiar

Tão dolente a cantar

Tengo, lengo, tengo, lengo,

tengo, lengo, tengo

$\mathrm{Ei}$, gado, oi

Bom vaqueiro nordestino

Morre sem deixar tostão
} 


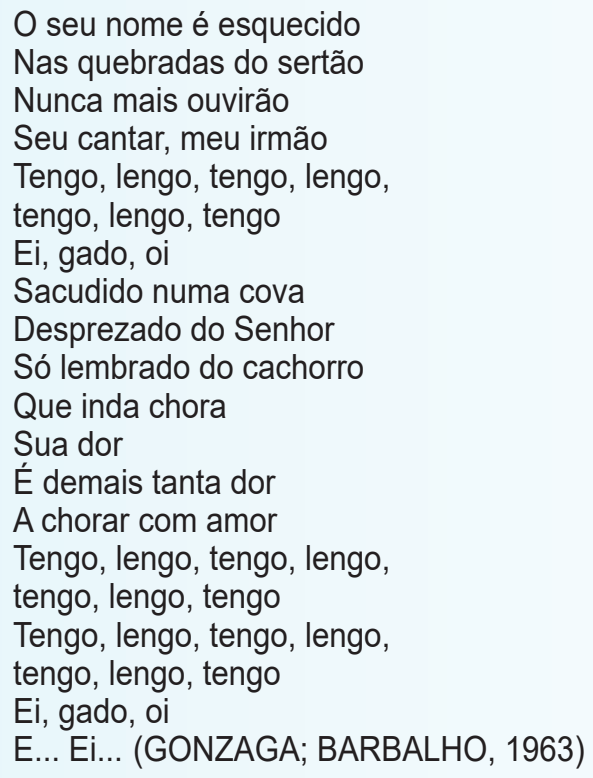

Ainda aqui, Gonzaga adiciona com maestria uma tonificação de louvor aos animais criados por Deus. Enquanto os homens esqueciam o morto, o de cujos era lembrado de um cachorro, que ainda chorava saudoso sua falta. Por causa deste episódio de injustiça contra o pobre que pedia uma melhor distribuição de renda para os brasileiros, foi composta a festejada "Missa do Vaqueiro". Em "vida do viajante", Gonzaga grita para seu filho Gonzaguinha: "Lulinha, olha o povão, não se esqueça do povão, meu filho" (GONZAGA; GONZAGUINHA, 1981).

Verdade que Gonzaga não pregava um assistencialismo esmolar destituído de um melhor planejamento, que, segundo ele, poderia até terminar ensejando vergonha no carente ou viciando aquele que recebe os benefícios. Antes, defendia o aumento das oportunidades de emprego para todos, tanto na zona rural quanto nas cidades. É o que reza, em seu poema:

Seu doutô os nordestino,

têm muita gratidão

Pelo auxílio dos sulista, nessa seca do sertão. 
Mas doutô uma esmola, a um homem qui é são

Ou lhe mata de vergonha, ou vicia o cidadão

[...] (GONZAGA, DANTAS, 1981)

Mister observar, ainda, nos poemas de Luiz Gonzaga, a intensa utilização de um português regional, falado pelo populacho, sem muito requinte ou observância sintática e léxica, o idioma de uma tradição miscigenada cuja oralidade ganhava relevância muito mais do que a língua escrita. Foi uma espécie de Mark Twain ${ }^{1}$ brasileiro, lançando na literatura o léxico falado pelo povo comum e iletrado, ensejando um novo idioma: o sertanês. Como disse Manuel Bandeira acerca do vocabulário do nordestino humilde: "A vida não me chegava pelos jornais nem pelos livros, vinha da boca do povo na língua errada do povo, língua certa do povo que fala gostoso o português do Brasil" (BANDEIRA, 1943). Essa nova forma de expressar o popular em sua arte, marcou grandemente a obra de Gonzaga, demonstrando, assim, seu apreço pelo quisquis de populo vendo beleza na autenticidade da simplicidade.

Gonzaga foi uma fonte inesgotável de arte. Foi poeta, cantor, compositor e ator, divulgando constantemente a música sertaneja, mas do sertão de verdade, de clima quente e solo ardente. Gonzaga soube utilizar a língua sem erudição, contando com a contribuição de todos os erros da prosódia e ortoepia sertanejas (NASCIMENTO, 2018, p. 34). Fez exuberância das máculas regulamentares do léxico que praticava.

\section{Reflexão sobre Ecoteologia ao modo de Gonzaga}

Numa curiosa historieta acerca do filósofo Heráclito, relata-se que um grande admirador foi ter com ele, sendo surpreendido, pois o filósofo não se encontrava isolado ou mergulhado em meditações profundas, mas era visto na cozinha e em meio a afazeres domésticos, sempre 
afirmando: "Aqui também se encontram os deuses" (CHAUÍ, 2012, p. 10). Seria possível, semelhantemente, encontrar-se com Deus também na natureza? Seria possível desencontrar-se dEle nela? A resposta de Gonzaga certamente seria positiva para ambos questionamentos. O rigor de seu deslumbramento com a criação, faz perceber a intensa reverência aos elementos formados por Deus, pregando repulsa àqueles que tratam os seres criados sem o rigor da diligência.

A primeira aparição de Deus aos humanos, conforme ensina o livro de Gênesis, (Gn. 1,27-29) foi num jardim, em meio a plantas e animais. A oração inaugural, portanto, foi numa igreja sem muros divisórios e torres de concreto, sem hierarquizados e leigos, sem fanus e profanus, onde toda ambiência era religiosa, sagrada e ecológica. O contato com Deus era direto e sem mediador, numa oração distante dos ritos e formulações regulamentares a burocratizar relações. E não se pode desprezar o magistério dos inícios, as lições ad fontes, os gritos exarados da raiz.

Ora, se o nascimento da relação divino-humana se deu num jardim, se as obras criadas carregam em si tons mais coloridos e verdejantes, se a conversa com o Pai era livre e solta, em foros holísticos, o que se pode aprender? A divindade, em sua inerência, é eminentemente ecológica. Podia, desde o início dos tempos, ter dito "haja prédio e concretos", "haja indústrias e cidades", mas não o fez. Preferiu priorizar o verde, a vida dos homens e outros animais. Ao pretender criar um ambiente propício ao desenvolvimento humano, no lugar de prédios, escolheu árvores. Seria um lecionário?

Quando desceu do céu para se encontrar com os humanos, Deus produziu o verde, mas quando os humanos desejaram subir para serem parecidos com Deus forjaram o cinza das grandes e orgulhosas construções e cidades. As construções começaram em Babel, quando os homens desejaram forjar para si fama, representando o desejo de poder e reconhecimento, como se depreende do relato bíblico: 
No mundo todo havia apenas uma língua, um só modo de falar. Saindo os homens do Oriente, encontraram uma planície em Sinear e ali se fixaram. Disseram uns aos outros: "Vamos fazer tijolos e queimá-los bem". Usavam tijolos em lugar de pedras, e piche em vez de argamassa. Depois disseram: "Vamos construir uma cidade, com uma torre que alcance os céus. Assim nosso nome será famoso e não seremos espalhados pela face da terra". O Senhor desceu para ver a cidade e a torre que os homens estavam construindo. E disse o Senhor: "Eles são um só povo e falam uma só língua, e começaram a construir isso. Em breve nada poderá impedir o que planejam fazer. Venham, desçamos e confundamos a língua que falam, para que não entendam mais uns aos outros". Assim o Senhor os dispersou dali por toda a terra, e pararam de construir a cidade. (Gênesis 11.1-8)

Neste aglomerado cinzento, quando se agigantou o ego e o brio, diminuiu-se o entendimento social, a comunicação passou a ser ruidosa, houve confusão. Certamente, acreditavam que no céu poderiam ser como Deus ou pelo menos encontrá-lo. Mas não se pode encontrar-se com Ele aqui ou acolá, mas aqui e acolá. O próprio Jesus afirmou: "Mas quando você orar, vá para seu quarto, feche a porta e ore a seu Pai, que está no secreto. Então seu Pai, que vê no secreto, o recompensará." (Mateus, 6,6). Isto é, aquele que é omne não se acanha em manifestar-se em todos os lugares. Dissimilis, a menor atenção com aquilo que Deus criou e viu ser bom, pode causar, ao revés, desencontros com o ideal divino. Há, portanto, na natureza uma valoração moral intrínseca, ela não está alheia do plano ético cristão. Deus se preocupa e cuida de tudo o que criou com mãos próprias ou delegadas.

Nos relatos da criação, percebe-se a ordem divina para que o homem tivesse domínio "sobre os peixes do mar, sobre as aves dos céus, sobre os animais domésticos, sobre toda a terra e sobre todos os répteis que rastejam pela terra". Interessante notar que a passagem sobrescrita (Gn. 1.26,b) está localizada no mesmo verso em que Deus diz: "Façamos o homem à nossa imagem, conforme a nossa semelhança...". Parece, portanto, que o domínio que o homem deveria ter sobre a cria- 
ção deveria repetir a responsabilidade divina. Durante muito tempo, esse "domínio" sobre a terra fora compreendido como um poder despótico, destituído de quaisquer responsabilidades, freios e contrapesos, como se a agenda da relação humano-natureza fosse pautada no laissez-faire, vinculada a uma anarquia gerencial distópica, cujo único objetivo seria a produção de valores imediatos, sem dar-se importância a contrapartidas e responsabilidades.

Sem voz, a pequena natureza geme sob a égide do autoritário. Os brilhantes chamam mais que sua mãe, a natureza. Os variados pequeninos empoeirados e minúsculos não têm vez no mundo de maiúsculos. Os samaritanos continuam caindo e os transeuntes permanecem se afastando, tergiversando ao encontro, passando ao largo dos mais estreitos, dos que caminham pela vida em constante carestia. As crianças, os doentes, idosos e pobres continuam obscurecidos aos olhos da maioridade, alijadas dos seus direitos, e, a terra, embaixo dos homens, permanece calada, muda e rebaixada, ferida junto com os animais. Quem Ihe dará voz?

Aquele que deveria ser mordomo serviçal, tornou-se explorador. Feito para gerir um mundo criado com cuidado, passou a mecanizá-lo com vistas a sugar toda a sua força, sem preocupar-se com o futuro de suas energias. Como um déspota malcriado, com grades, arados e enxadas a meta era o ferir com ferro a epiderme do solo para exploração, não visando a multiplicação, tornando-a escrava a trabalhar sob açoites e pernoites. Ao atravessar o solo, sem atenção solidária, ao abrir novas sendas e vias, pulverizar sementes e vitaminá-lo com adubos, pretendia-se tão somente frutos, não importando se morresse as matas, não importando que permanecesse a fome ou fossem extintos os animais. Sem dar à terra a sua própria porção de grãos, sem conceder-lhe o sábado, o ar para respirar, rebaixou-a a instrumentário, encravando-a na cruz. Quem há de ressuscitá-la?

A relação homem-natureza perdeu a naturalidade, transformando- 
-se em imaturidade. O pastor da terra, tornou-se lobo, predador salivante por tirar todo o sumo possível da Mãe-Filha natureza. Mas se se compreende a relação entre o domínio exercido pelo homem sobre a criação em medida semelhante ao operado por Deus, ter-se-á uma imagem mais servil que exploradora. Com efeito, o fundamento da liderança humana sobre a criação é o cuidado e o serviço. Quanto mais alto se é projetado, maior deve ser o reclinar. Esse foi o exemplo dado por Jesus. Ao tornar-se carne, diminuiu-se para servir, despojando-se dos lugares altos e ricos para habitar nos vales miúdos dos recantos das vaidades, lecionando o magistério nobre da descida. A verdadeira religião enseja impulsos para baixo. Assim Jesus ensinou, ao tomar a bacia, a toalha e o pano para limpar as partes humanas mais humildes, atendendo com diligência e cuidado os pés dos apóstolos, dos quais todos se evadiam. A própria etimologia da palavra "humilde", relaciona-se a "húmus", terra, que desde as inerências carrega consigo a nobreza de sua posição mais baixa. Devido à vocação singular, foi, como Cristo, desprezada, andou na via crucies, terminando pregada numa cruz exploratória, donde precisa ser descolada pelas mãos dos que veem com os olhos divinos e ouvem com seus ouvidos.

Gonzaga, mais do que qualquer outro, no seu cancioneiro demonstra tal referencial. Não via o homem como um comandante destituído de responsabilidade, mas que devia cuidar e zelar de todas as coisas criadas por Deus. Não se trata, bem verdade, de tirar a coroa do caçula da criação, único feito à imagem e semelhança do criador, mas de identifica-lo ainda mais com Ele, em cujo cetro há, acima de tudo, responsabilidade e serviço.

O homem pós-moderno se surpreende mais com prédios altos, menos com ipês roxos. Sua atenção é cativada mais pelas enormes e variadas torres que pelo pé de laranja e goiabeira. Em Gonzaga, o inverso é mais verdadeiro, a beleza original encontra em seus versos mais festejos. O barro é louvado mais do que o concreto, as pinturas provenientes dos pinceis de Deus muito mais do que os rabiscos humanos. Via a perfeição 
do céu postado sobre as terras longínquas do Nordeste, mas escondido tímidos nas grandes cidades, e o exaltava em poemas apaixonados. Descrevia em pormenor as plantas e os animais de sua região, bem como as profissões mais populares naqueles interiores. Conversou com o Juazeiro, descreveu a força e a sagacidade do jumento, as festas no pé de serra e os namoros sob o lindo luar do sertão, tudo isso com tons de lirismo e toques de ironia. Acerca disso relata Nascimento (2018, p. 41):

Luiz Gonzaga foi uma novidade no Sudeste pelo seu jeito bonachão de ser, pela sua atitude de desprendimento, o sotaque peculiar, o hábito de contar os seus casos para introduzir as canções, misturando canto e narrativa oral. Por meio da gestualidade, da indumentária, da voz, dos símbolos presente nas letras das músicas, encontramos grande parte dos temas recorrente em toda literatura sobre o sertão nordestino. Luiz Gonzaga nos apresenta ele mesmo como mensagem viva. A partir de diversos recursos poéticos e expressivos que marcam a sua performance, o artista presentifica um Nordeste vivo e vibrante que pulsa no canto dos animais, na solidão das longas estradas, no aboio de vaqueiros, no cantar das jias as lagoas durante o período das cheias ou na canto de mau agouro das acauãs. No ritmo de sua música, podemos ouvir o galopar dos cavalos, o relinchar dos jumentos, o passo das boiadas, o gemer dolente dos vaqueiros, o canto piedoso das procissões. Ele interpreta o mundo do sertão nordestino de maneira singular, reunindo-o ao ato de cantar [...] Luiz Gonzaga soube transformar em arte a existência do sertanejo

Luiz Gonzaga foi grande por se fazer simples e pequeno, e, ao abaixar-se, foi surpreendido com a beleza ali encontrada. À guisa de poço, sua profundidade gerou água. Muitas vezes, os valores mais importantes encontram-se subsolados como diamantes. Na vida religiosa, nalgumas vezes, sói acontecer semelhante, o menor encontra mais tesouros. Assim como nos termos matemáticos da "regra três", o menos acaba valendo mais. Em seu magistério, João Batista ensinou a rigor o que aprendeu de Deus: necessitava diminuir-se para permitir o verdadeiro crescimento. A exaltação do divino começa na subtração. Em lugar de olhar para o alto, a religião deve também ver mais embaixo, pois quem 
não consegue ler os homens como descortinará a Deus? Quem não enxerga a terra, como verá o céu?

Numa outra dimensão, a vida de Gonzaga não permaneceu reduzida a um repertório teorético, mas enfrentou de pulso firme as questões políticas e sociais de seu tempo. Era um sujeito engajado, que pleiteava por mudanças práticas na região em que vivia. Suas canções se misturavam a petições ao poder público, incentivando governantes a atuarem mais verticalmente nas questões do sertão nordestino, como atesta a canção "Vozes da Seca":

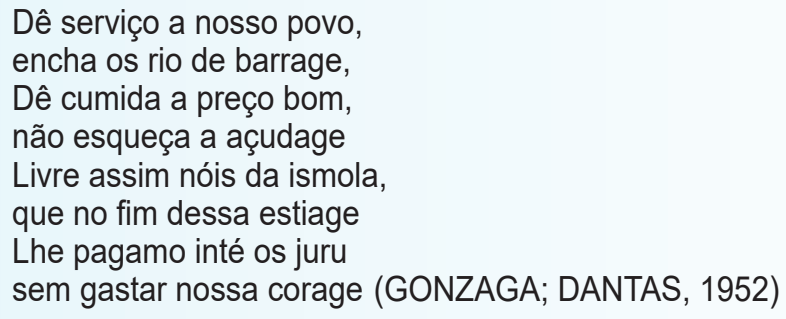

Relata Nascimento (2018, p. 35): "Gonzaga foi ainda um grande político. Com a popularidade que alcançou por meio de sua atividade artística, promoveu mudanças concretas para a vida dos sertanejos". Assim discursou o senador Marco Maciel (Apud NASCIMENTO, p. 36), numa homenagem ao "Rei do Baião":

Não foi graças a sua voz que o drama nordestino, especialmente da seca e estiagens, adquiriu uma consciência nacional e se transformou em questão a exigir a atenção e atuação do poder central? A seca, como é notório, não é um fenômeno novo, mas, recorde-se, a música de Luiz Gonzaga ajuda a convertê-la em desafio para os governantes... Através de "Asa Branca" - a sua asa branca era a pomba da paz - Gonzaga elevou à condição de epopeia a questão nordestina.

Segundo Gonzaga, o próprio Juscelino Kubitscheck, deputado à época, e aquele que criaria a Sudene, afirmara que o baião de Gonzaga valia muito mais que seus discursos (GONZAGA; GONZAGUINHA, 1981) 


\section{Conclusão}

A riqueza de temas referentes à ecologia recheia sobejamente o cancioneiro gonzaguiano. Chama à atenção as inúmeras ilustrações e variadas analogias utilizadas que retornam constantemente ao tema central de sua vida, qual seja, a natureza, seu cuidado e beleza. Em tudo isso, Gonzaga sempre desenvolveu uma visão otimista, mesmo quando tecia comentos a respeito das tragédias comuns da vida. Da seca fez graça, não gracejo. Não brincava com a dor sertaneja, mas preferiu impedir que esta fulminasse o lado bom de toda a existência, sem ofuscar a beleza presente mesmo nas feridas.

Em Gonzaga, vê-se presente os fundamentos do homo viridi, do homem ecológico e verdejante, que prefere caminhar ao lado da natureza e não sobre ela, elegendo a parceria em lugar do grilhão e chicote, sujeito que se faz mordomo ecológico a cuidar do que não lhe pertence, aquele que entende o real sentido contido em Gênesis do dever humano em relação à terra e aos seres criados.

A alcunha de "Rei" parece caber bem em Luiz Gonzaga, pois a verdadeira realeza não permite que de tronos se façam esporas, nem que se degenere em morte a vida, transformando o verde vivo em vozes secas. Gonzaga amou a natureza. Fez da terra amante, amiga com a qual se deliciava mesmo quando permanecia magra e raquítica. Seus laços de amor com a natureza era, como ensinou o apóstolo, "sofredor" (1. Cor. 13.4a). Permaneceu amigo da terra e da natureza não obstante as intempéries e tragédias próprias da vida.

\section{Referências}

ALBIN, Ricardo Cravo. O livro de ouro da MPB. $3^{a}$ edição. São Paulo: Ediouro, 2004

AQUINO, Filipe. Por que Francisco é o protetor dos animais. Disponível em https://formacao.cancaonova.com/igreja/santos/por-que-sao-francisco-eo-protetor-dos-animais/, acesso em 30 de janeiro de 2019

BANDEIRA, Manuel. Evocação do Recife. Disponível em https://www.escritas.org/pt/t/9074/evocacao-do-recife, acesso em 26 de janeiro de 2019. 
CHAUÍ, Marilena. $6^{a}$ edição. Convite à filosofia. São Paulo: editora Ática, 2012.

CUNHA, Euclides da. Os Sertões. São Paulo: Três, 1984 (Biblioteca do Estudante).

LACERDA, Jorge Balleeiro. Os dez Brasis: 500 anos da terra dos papagaios, Francisco Beltrão: Grafit, 1999

GOIS, Anselmo. Coronel Horácio de Matos. O Caudilho do Sertão: Programa de Lá Pra Cá TV Brasil, Direção Valber Carvalho e Dulce Pandolfi, 2013. Disponível em https://www.youtube.com/ watch?v=JE6KFHX2PUo, acesso em 29 de janeiro de 2019.

GONZAGA, Luiz; BARBALHO, Nelson. A morte do vaqueiro. Disponível em https://cifrantiga3.blogspot.com/search?q=morte+do+vaqueiro. Acesso em 09 de mar. de 2019.

GONZAGA, Luiz; CAVALCANTI, Armando; CALDAS, klecius. Boiadeiro. Disponível em https://cifrantiga3.blogspot.com/search?q=boiadeiro. Acesso em 09 de março de 2019.

GONZAGA, Luiz; CLEMENTINO, José. Apologia ao jumento. Disponível em https://www.google.com.br/search?ei=05BYXJaLNeby $5 \mathrm{gKDgrGYBQ \& q}=$ apologia+ao+jumento\&oq=apologia+ao+jumento\&gs

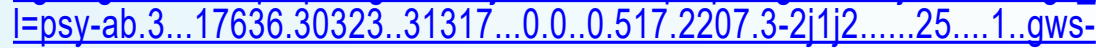
-wiz......0i71.Kvs1zAGUjBc, acesso em 01 de fevereiro de 2019.

GONZAGA, Luiz; DANTAS, José. Vozes secas. Disponível em https://www. youtube.com/watch?v=YOmL8EJedUs. Acesso em 09 de mar. de 2019.

GONZAGA, Luiz; GOZAGUINHA, Luiz. Gonzagão e Gonzaguinha ao vivo: a vida do viajante. Rio de Janeiro: BMG, CD. 1981. 1 hora e 29 minutos.

GONZAGA, Luiz; TEXEIRA, Humberto. Assum Preto. Disponível em https://cifrantiga3.blogspot.com/search?q=ASSUM+PRETO. Acesso em $0 \overline{09}$ de mar. de 2019.

GONZAGA, Luiz; TEXEIRA, Humberto. Estrada de Canindé. Disponível em https://cifrantiga3.blogspot.com/search?q=juazeiro. Acesso em 09 de mar. de 2019.

GONZAGA, Luiz; TEXEIRA, Humberto. Juazeiro. Disponível em https:/l cifrantiga3.blogspot.com/search?q=boiadeiro. Acesso em 09 de mar. de 2019.

HOUAISS, Antonio. Dicionário da música popular brasileira. Rio de Janeiro: Paracatu., 2006.

NASCIMENTO, Nildecy de Miranda. Luiz Gonzaga: um contador do Nordeste do Brasil. Curitiba: Appris, 2018. 